\title{
Save Generation from Substance Abuse
}

\author{
doi: http://dx.doi.org/10.3329/jemc.v6i3.29677
}

Globally across cultures and throughout history man has taken substances that affect mind and alter the quality of consciousness. In the last 100 years unacceptable drug taking has been an increasing area of social concern. Drug taking behavior and its consequences have come into the domain of psychiatric illness. In 1950, WHO defined drug addiction as 'A state of periodic or chronic intoxication detrimental to the individual and to society produced by the repeated consumption of a drug (natural or synthetic); characteristics include 1) an overpowering desire or need (compulsion) to continue taking the drug and to obtain it by any means; 2) a tendency to increase the dose; 3) psychic (or psychological) and sometimes physical dependence on the effects of the drug; and 4) a detrimental effect on the individual and on society'. ${ }^{1}$ In 1964, WHO recommended that 'dependence' was preferred term. But in 1967, 'drug abuse' was introduced finally by WHO. ' 'Misuse' is classified as harmful use in International Classification of Diseases- $10^{2}$ and 'abuse' in Diagnostic and Statistical Manual of Mental Disorders-IV. ${ }^{3}$

The 2009 national survey on Drug use and Health in USA found that $8.7 \%$ of the population aged 12 years or over had used an illicit substance in the past month. It was highest in unemployed people in 16-25 years age range. The most commonly used illicit drug was cannabis (58\%). Highest rate of drug use in the last year was seen in men aged 25-34 years $(28.9 \%)$ and women aged 16-24 years (21.9\%). But in general highest frequency was in the 16-24 years of age group. ${ }^{4}$ Problems of drug takers include psychological, physical, social or legal; problems related to intoxication and/or regular excessive consumption, and/or dependence as a consequence of use of drugs or chemical substances.

Twelve classes of pharmacological agents used for addiction are alcohol, amphetamine or similar agents, caffeine, cannabis, cocaine, hallucinogens, inhalants, nicotine, opioids, phencyclidine or similar agents, sedatives-hypnotics-anxiolytics, anabolic steroids and nitrous oxide. Repeated drug use produces changes in the central nervous system. Addictions may have effects on the activities of specific reward areas of the brain such as ventral tegmental area, the locus ceruleus and the nucleus accumbens. Drug-related stimuli increase activity in limbic system including amygdale and anterior cingulate. ${ }^{5}$ Addiction is a 'brain disease' in which the critical processes transform voluntary drug-using behavior to compulsive drug use causing changes in the structure and neurochemistry of the brain. The major neurotransmitters possibly involved in substance dependence are opioids, dopamine and GABA systems. ${ }^{5}$

There is no single cause of drug misuse. Important factors are availability of drugs, a vulnerable personality, an adverse social environment, peer pressure, pharmacological factors and individual biology.

Causes may remain in psychodynamic factors such as: substance abuse is a masturbatory equivalent (initial euphoria as similar to prolonged sexual orgasm); defense against anxious impulses; manifestations of oral regression (due to faulty parenting, fixation occurs in the infant's oral stage [birth to age one], then in later age the child develops dependency); disturbed ego-functions (inability to deal with reality); self-medication to control panic, anger and depression. Rapid positive reinforcement includes drug-induced euphoria and secondary reinforcement includes observing cigarette packs, bottles, needles, sound and smells of substances. Psychological dependence develops in which substance-seeking behavior with pathological use pattern occurs. Ultimately habituation develops along with craving for the substances to avoid dysphoric state.

Consequences of intravenous drug misuse are venous thrombosis, infection at injection site, damage of arteries, bacterial endocarditis, hepatitis B and C, AIDS, accidental overdose and death. In case of 
mother, fetal abnormality, stunted fetal growth and fetal alcoholic syndrome may occur. Social consequences are: premature death, physical and mental illness, low education, unemployment, adverse effect on children, poverty, crime, road traffic accident, absence from job, theft and productivity loss. Family members show anger, rejection, failure, guilt feelings and depression. These types of behaviors of family members are called co-dependency.

Alcohol and substance abuses are strictly forbidden in Islam. In the Holy Quran, prohibition of alcohol consumption has been narrated in four stages by five verses (Surah An-Nahl, verse 67; Surah Al Bakarah, verse 219; Surah An-Nisa, verse 43 and Surah AlMaidah, verses 90, 91). ${ }^{6}$ In Sahih Al-Bukhari (Chapter: Kitabul Ashriba) 27 hadiths were included against alcoholism.

United Nations declared $26^{\text {th }}$ June as 'International day against drug abuse and illicit trafficking'. This year the slogan of the day was 'Listen FIRST; listening to children and youth is the first step to help them grow healthy and safe'. Control of substance dependence depends upon three activities: 1) demand reduction (public awareness and motivation), 2) supply reduction (anti-drug trafficking activities by law-enforcers and public participation) and 3) harm reduction (by detoxification and rehabilitation centers). By active implementation of all these activities, the risk of substance abuse can be reduced to a great extent.

\section{Dewan AKM Abdur Rahim}

Professor, Department of Psychiatry

Enam Medical College \& Hospital

Savar, Dhaka

\section{References}

1. Thorley A. Drug problems. In: Hill P, Murray R, Thorley A (eds). Essentials of postgraduate psychiatry. $2^{\text {nd }}$ edn. London: Grune \& Stratton Inco., 1986: 381-403.

2. WHO (eds). ICD-10. Geneva: Oxford University Press Delhi, 1994.

3. American Psychiatric Association (eds). DSM-IV. Washington DC: First Indian Edition 2005.

4. Cowen P, Harrison P, Burns T (eds). Shorter Oxford textbook of psychiatry. $6^{\text {th }}$ edn. UK: Oxford University Press, 2012: 463-482.

5. Substance-related disorders. In: Sadock BJ, Sadock VA (eds). Kaplan \& Sadock's synopsis of psychiatry. $10^{\text {th }}$ edn. New York: Wolters Kluwer, 2007: 381-466.

6. Khan MM, Al-Hilali MT. The Noble Quran. Riyadh: Darussalam Publishers \& Distributors, 2007: 57, 127, 174, 365 . 